\title{
Patterns of Motivational Orientation and its Relationship with Academic Performance in University Students
}

\author{
María Arely López Garrido ${ }^{1}$, Erika Yunuen Morales Mateos ${ }^{1}$, \\ José Alberto Hernández Aguilar ${ }^{2}$, Carlos Alberto Ochoa Ortíz ${ }^{3}$, \\ Carolina González Constantino ${ }^{1}$, Oscar Alberto González González ${ }^{1}$ \\ ${ }^{1}$ Universidad Juárez Autónoma de Tabasco Cunduacán, Tabasco, Mexico \\ ${ }^{2}$ Universidad Autónoma del Estado de Morelos, Cuernavaca, Morelos, Mexico \\ ${ }^{3}$ Universidad Autónoma de Ciudad Juárez, Ciudad Juárez, Chihuahua, Mexico \\ arely.lopez@ujat.mx, erika.morales@ujat.mx, jose hernandez@uaem.mx, \\ alberto.ochoa@uacj.mx, carolina.gonzalez@ujat.mx, oscar.gonzalez@ujat.mx
}

\begin{abstract}
This research aims to identify the learning strategies employed by university students; and represent them through graphic techniques of multivariate analysis. The sample consisted of 30 students from the Multidisciplinary Academic Division of the Rivers; of the degrees in Administration and Administrative Computing of the generational cohorts 2010, 2011 and 2012. The instrument used is the Inventory of Strategies of Learning and Motivational Orientation (EDAOM) this instrument consists of a self-assessment that the student makes on the learning strategies that employs. For the implementation of the visual techniques was used the Language $\mathrm{R}$, with these techniques were represented individually to the students with their respective learning strategies. The results show the interaction of the students with the learning strategies and the academic performance, visualization that the students of the Degree in Administrative Computing obtain the lowest values in the strategies of performance and academic performance.
\end{abstract}

Keywords: apriori, EDAOM, academic performance, visualization, associationrRules.

\section{Introduction}

The academic performance is an indicator that directly affects the terminal efficiency and the achievement rate, these are indicators that are evaluated in the accreditations of the Educational Programs, therefore for the Institutions of Higher Education it is necessary to increase the academic performance of the students, reduce the disapproval and abandonment to achieve the rates of achievement and terminal efficiency [1], for this reason it is important for Higher Education Institutions to know the factors that affect these indicators and thus implement strategies that help its improvement, likewise the IES perform their administrative procedures and activities through the use of transactional information systems generating a large amount of data, however in many cases these data are not used to generate useful knowledge that supports the decisionmaking process. the academic administration for the implementation of strategies. 
Likewise, since 2000, ANUIES has formulated the document Higher Education in the 21st Century, which includes the Integral Development of Students program, which aims to support students with tutoring and integral development programs to complete their studies in the deadline and achieve the training objectives established in the plans and syllabuses.

Consequently, the IES implemented the Tutoring Programs with the aim of reducing the dropout and failure by improving the use and as a result the terminal efficiency indexes [2], a support tool for tutors is the inventory of Learning Styles and Motivational Guidance. (EDAOM) that is applied to students to identify if students need to reinforce their learning strategies and motivational guidance to study to achieve better academic performance [3].

In this study, the objective is to identify the EDAOM motivational orientation variables that influence academic performance through association rules.

\subsection{Related Work}

Different studies have been carried out in which data mining techniques are applied to identify the factors associated with academic performance and student desertion. For example, in the Technological Studies of Jocotitlán, a study was conducted to know the factors that cause the School dropout using data mining association rules using data from economic, family and academic backgrounds found various patterns on the factors that determine student desertion [4], likewise Rodríguez-Maya et al. [5], propose a model to predict the desertion based on the information of the entrance examination and self-reported by students, the obtained model has an accuracy of $86 \%$.

Another study carried out to know the factors that most influence the results obtained from the EXANI-II exam for admission to higher education of CENEVAL, to determine the attributes that most influenced the use of Principal Component Analysis techniques, for the classification methods used algorithms of rules, trees, Bayes, and lazy algorithms and metaalgorithms, obtained as a result that the attributes that most influence the performance of the exam are hours worked, high school average, year of birth of the student, number of books in the student's home and schooling both parents [6].

Márquez et al [7] conducted a study using data mining classification techniques to detect the factors that most influence secondary school students to drop out. They conclude that classification algorithms can be used to predict performance.

On the other hand, advances in the development of automatic information processing tools have provided the creation and use of data analysis techniques [8], generating increasingly sophisticated, dynamic and interactive graphics to visualize data or models [9], likewise, through visual representation, the relationships described by the graphs are easily understood and easy to remember [10], in this context of data visualization work has been done that show the use of techniques and tools applied to the analysis of educational data $[11,12]$.

\subsection{Association Rules}

Association rules express patterns of behavior between data in a database. The rules express the combinations of attribute values that occur most frequently [13]. 
A rule of association can be seen as rules of the form IF $\alpha$ THEN $\beta$, where $\alpha$ and $\beta$ are two sets of disjoint items. The measures to know the quality of an association rule are the coverage (support) and confidence (confidence). Coverage is defined as the number of instances that the rule predicts correctly. Confidence measures the percentage of times the rule is met when it can be applied [13].

A simple and popular association rules learning algorithm is the Apriori, this algorithm is based on the search of the sets of items with certain coverage, in the first place the sets formed by only one item that exceed the minimum coverage are constructed. This set of sets is used to construct the set of item sets, and so on until a size is reached in which there is no set of items with the required coverage [13].

\section{$2 \quad$ Method and Tools}

The scope of this research is descriptive because they will specify properties and characteristics describing trends, the design is non-experimental transectional [14]. The method used in this work is that of the knowledge extraction process that is composed of the following phases: data collection, pre-processing, data mining and interpretation of results [15].

The purpose of this paper is to show the existing associations between academic performance and EDAOM variables: perceived effectiveness, internal contingency, perceived autonomy and orientation to external approval including academic and socioeducational variables. The population is made up of new students belonging to the cohorts 2010, 2011 and 2012 of the Bachelor Degrees: Aquaculture Engineering, Food Engineering, Bachelor of Administration, Bachelor of Law, Bachelor of Nursing and Bachelor of Computer Science of the Multidisciplinary Academic Division of the Rivers (DAMR) of the Universidad Juárez Autónoma de Tabasco (UJAT), the sample was non-probabilistic, directed and for convenience; and is composed of 297 students.

\subsection{Inventory of Learning Strategies and Motivational Orientation (EDAOM)}

The instrument used was the EDAOM questionnaire, the result of this questionnaire is a self-assessment that the student makes about their learning strategies and motivational orientation to the study [3]. The self-report section measures self-assessments of students on: a) frequency, b) ease or difficulty, and c) the results of using a wide variety of learning strategies.

The EDAOM is composed of four scales and 13 subscales; the Self-regulation, Metacognitive and Metamotivational scale consists of three components: those of the person, those of the learning task and learning materials; Table 1 shows the structure of the EDAOM, the first column specifies the scales and the second the subscales that make it up.

In this work the subscales of the EDAOM are considered perceived efficiency, internal contingency and perceived autonomy. The perceived effectiveness refers to the student's evaluation of the strategies used to study and learn, the contingency refers to the student and recognizes the demands of the task What is required in class, autonomy is how dependent or independent is the student perceived to achieve their learning [16]. 
María Arely López Garrido, Erika Yunuen Morales Mateos, José Alberto Hernández Aguilar, et al.

Table 1. EDAOM scales and subescales.

\begin{tabular}{ll}
\hline Scales & Subscales \\
\hline Acquisition of information & $\begin{array}{l}\text { Selective } \\
\text { Generative }\end{array}$ \\
Recover of information & $\begin{array}{l}\text { Subjected tasks } \\
\text { During exams }\end{array}$ \\
Processing information & Convergent \\
& Divergent \\
& $\begin{array}{l}\text { Person: Efficiency perceived Internal Contin- } \\
\text { gency }\end{array}$ \\
& $\begin{array}{l}\text { Perceived autonomy } \\
\text { Orientation to external approval }\end{array}$ \\
Self-regulation, Metacogni- & Learning Task: Orientation to the task itself \\
tive and Metamotivational & Orientation to the achievement of goal \\
& \\
\hline
\end{tabular}

\subsection{Software Used for Data Analysis}

A very important element to implement data analysis techniques are the tools, in this case the $\mathrm{R}$ language was used.

$\mathrm{R}$ is a free software of statistical computing and graphics. Compile and run and compile on a variety of UNIX, Windows and MacOs platforms. It is widely used for the development of statistical software and data analysis, provides a wide variety of statistical models: linear and non-linear models, classical statistical tests, analysis of time series, classification, grouping among others) and graphic techniques. $\mathrm{R}$ is an environment in which statistical techniques are implemented and that is extensible through the packages, there are around eight packages that are supplied with the distribution of $\mathrm{R}[17]$.

\section{$3 \quad$ Results}

The data set is composed of 297 records of new entrants of the 2010-2011 and 2011 generational cohorts, that of the EDAOM taken into consideration for this work is the self-regulation, metacognitive and metamotivational person dimension that make up the subscales: effectiveness, contingency, autonomy and approval, the criteria used for the interpretation of the results of the EDAOM evaluation are shown in Table 2.

The set of data for the generation of the rules is composed of 297 records of new entrants of the degrees of: Aquaculture Engineering, Food Engineering, Administration, Administrative Computing, Law and Nursing; by the nature of the type of study and the algorithm to implement the data were discretized; Table 3 shows the correspondence between the attribute, the type of data and its corresponding value, the attributes that identify groups of students are: career, sex, age, high school graduates; 
EDAOM variables: effectiveness, contingency, autonomy and approval; variables of academic trajectory such as: enrolled subjects, approved subjects, average of marks in ordinary exams and academic performance in addition to the variables of expectations of maximum degree of studies to reach, studies of the mother and studies of the father.

Table 2. EDAOM evaluation performance criteria.

\begin{tabular}{ll}
\hline Score & Interpretation \\
\hline $100-76$ & $\begin{array}{l}\text { Indicates that the students has a good } \\
\text { development of learning strategies } \\
\text { Indicates a regular result, so the corresponding } \\
\text { subscales have to be reinforced. } \\
\text { Indicates an insufficient result, which is why } \\
\text { you have to train the learning strategies }\end{array}$ \\
\hline
\end{tabular}

Table 3. Set of attributes used to generate rules.

\begin{tabular}{|c|c|c|}
\hline Atribute & $\begin{array}{l}\text { Measurem } \\
\text { ent } \\
\text { scale }\end{array}$ & Values \\
\hline $\begin{array}{l}\text { Bachelor's } \\
\text { degree }\end{array}$ & Ordinal & $\mathrm{IAC} / \mathrm{LA} / \mathrm{AL} / \mathrm{LD} / \mathrm{LE} / \mathrm{LIA}$ \\
\hline EST ALC & Ordinal & TSU/LICENCIATURA/POSGRADO \\
\hline ESC_MAD & Ordinal & $\begin{array}{l}\text { NOESTUDIO/PRIMARIA/SECUNDARIA } \\
\text { /BACHILLERATO/CARRERATECNICA/ } \\
\text { LICENCIATURA/POSGRADO }\end{array}$ \\
\hline ESC_PAD & & $\begin{array}{l}\text { NOESTUDIO/NOLOSE/PRIMARIA/SEC } \\
\text { UNDARIA/BACHILLERATO/CARRERA } \\
\text { TECNICA/LICENCIATURA/POSGRADO }\end{array}$ \\
\hline SEXO & Nominal & $\mathrm{F} / \mathrm{M}$ \\
\hline EDAD & Ordinal & $\mathrm{A} / \mathrm{B} / \mathrm{C} / \mathrm{D} / \mathrm{E} / \mathrm{F} / \mathrm{G} / \mathrm{H} / \mathrm{I}$ \\
\hline PROM_BACH & Ordinal & $\begin{array}{l}\text { EXCELENTE/MUYBIEN/BIEN/REGULA } \\
\text { R/SUFICIENTE }\end{array}$ \\
\hline MAT_INS & Ordinal & $\begin{array}{l}\text { SEIS/SIETE/OCHO/DIEZ/ONCE/DOCE/T } \\
\text { RECE/DIECISEIS/DIECISIETE }\end{array}$ \\
\hline MAT_ACRE & Ordinal & $\begin{array}{l}\text { CERO/UNA/DOS/TRES/CUATRO/CINC } \\
\text { O/SEIS/SIETE/OCHO/NUEVE/DIEZ/ON } \\
\text { CE/DOCE/TRECE/CATORCE/QUINCE/ } \\
\text { DIECISEIS }\end{array}$ \\
\hline PROM ORD & Ordinal & BAJO/REGULAR/ALTO \\
\hline $\mathrm{DES} \overline{\mathrm{ACA}}$ & Ordinal & BAJO/REGULAR/ALTO \\
\hline EFICACIA & Ordinal & BAJO/REGULAR/ALTO \\
\hline $\begin{array}{l}\text { CONTINGENC } \\
\text { IA }\end{array}$ & Ordinal & BAJO/REGULAR/ALTO \\
\hline AUTONOMIA & Ordinal & BAJO/REGULAR/ALTO \\
\hline
\end{tabular}

The Apriori algorithm was applied, using the arules package [17] of the R language, for the generation of the rules a support ( $\mathrm{s}$ ) of at least 0.2 was specified and a confidence (c) of at least 0.9 obtaining 85 rules in total, below are six rules considered most relevant: 
Rule 1:

DES_ACAM=BAJO,EFICACIA=BAJO $\}=$ $\{$ AUTONOMIA=BAJO $\quad \mathrm{s}=0.3468013 \mathrm{c}=0.9626168 \mathrm{co}=103$

This rule specifies that if the student has a low academic performance and in the selfassessment of the strategies used they were effective, it is equal to low then it has a low performance.

\section{Rule 2:}

$\{$ PROM_A_ORD=BAJO,AUTONOMIA=BIEN $\}$

$\{$ DES_ACAM=BAJO $\} \mathrm{s}=0.2828283 \mathrm{c}=1.000000 \mathrm{co}=84$

This rule indicates that students who have a low average in ordinary exams and are perceived as independent in their learning then obtain low academic performance.

Rule 3:

$\left\{\mathrm{EST} \_\mathrm{ALCA}=\mathrm{POSGRADO}, \mathrm{SEXO}=\mathrm{M}\right\} \quad \Rightarrow \quad\{$ AUTONOMIA $=\mathrm{BIEN}\}$ $\mathrm{s}=0.2558923 \mathrm{c}=0.9047619 \mathrm{co}=76$

This rule indicates that if the students have the expectation of studying a postgraduate course and they are male, they are considered independent in their learning.

Rule 4:

$\{$ EST_ALCA=POSGRADO, PROM_A_ORD=ALTO

$\{$ DES_ACAM=ALTO $\} \quad \mathrm{s}=0.3131313 \mathrm{c}=0.9300000 \mathrm{co}=93$

This rule indicates that students who have the expectation of studying a graduate degree and have an average of high ordinary then their academic performance is high.

Rule 5:

$\{$ SEXO=F, PROM_A_ORD=ALTO, AUTONOMIA=BIEN $\} \quad \Rightarrow$ $\{$ DES_ACAM $=$ ALTO $\} \quad \mathrm{s}=0.2121212 \mathrm{c}=0.9843750 \mathrm{co}=63$

This rule indicates that students who have a high average of ordinary exams and that are considered independent in their learning obtain a high academic performance

Rule 6:

$\{$ PROM_A_ORD=ALTO, CONTINGENCIA=BIEN,AUTONOMIA=BIEN $\} \quad \Rightarrow$ $\{$ DES_ACAM $=$ ALTO $\} \quad \mathrm{s}=0.2020202 \mathrm{c}=0.9090909 \mathrm{co}=60$

This rule indicates that students with high average of ordinary exams, which recognizes the demands that tasks require and is considered independent in their learning have a high academic performance.

\section{Conclusions}

In this work the objective of identifying the subscales of metamotivational orientation that influence the academic performance of university students was achieved, these are self-nomination, effectiveness and contingency, likewise, it is distinguished that if the student has a high motivation to improve by having as expectations to study a postgraduate this is a variable that affects academic performance. 
It is observed that students who have a good result in autonomy is to say that they consider themselves independent in their learning that does not depend on others and that they have a good self-assessment in the effectiveness of the learning strategies used and that they know how to recognize the demands The task demands they have a high academic performance.

\section{References}

1. Romo-López, A.: La tutoría: una estrategia innovadora en el marco de los programas de atención a estudiantes Asociación Nacional de Universidades e Instituciones de Educación Superior, Dirección de Medios Editoriales (2011)

2. Universidad Juárez Autónoma de Tabasco: Programa Institucional de Tutorías (2003)

3. Castañeda, S.: Educación, aprendizaje y cognición. Teoría en la práctica. México. El Manual Moderno S.A. de C.V. (2004)

4. Reyes-Nava, A., Flores-Fuentes, A., Alejo, R., Lara, E.R.: Minería de datos aplicada para la identificación de factores de riesgo en alumnos. Research in Computing Science 139, pp. 177-189 (2017)

5. Rodríguez-Maya, N., Lara-Álvarez, C., May-Tzuc, O., Suárez-Carranza, B.A.: Modeling Student Dropout in Mexican Universities. Research in Computing Science 139, pp. 163175 (2017)

6. González-Marrón, D., Enciso-Gonzalez, A., Hernandez-Gonzalez, A.K., Gutierrez-Franco, D., Guizar-Barrera, B., Marquez-Callejas, A.: Evaluación de parámetros de encuesta de ingreso del CENEVAL para alumnos candidatos a ingresar al nivel superior, caso de estudio ITP. Research in Computing Science 139, pp. 135-147 (2017)

7. Márquez-Vera, C., Romero-Morales, C., Ventura-Soto, S, Ventura, S.: Predicción del Fracaso Escolar mediante Técnicas de Minería de Datos. IEEE-RITA 7(3) (2012)

8. Pérez, M.: Minería de Datos a través de ejemplos. México. Alfaomega Grupo Editor S.A. de C.V (2014)

9. Ledesma, R., Molina, J., Forrest, W., Valero-Mora, P.: La visualización múltiple en el análisis de datos: una aplicación en ViSta para el análisis de componentes principales. ISNN 01214-9915. Psicothema 19(3), 497-505. http://www.uv.es/molina/journal_publications/2007_vis_multiple.p (2007)

10. Sáez, M.: Diseño e implementación de una aplicación en Processing para la representación de datos multidimensionales. (2015)

11. Lopez-Garrido, M.A., Hernández-Aguilar, J.A., Ochoa-Ortiz Zezzatti, C.A., MoralesMateos, E.Y., González-Constantino, C.: Comparative Study of Learning Strategies of Bachelor Students in Nursing. Research in Computing Science 122, pp. 153-162 (2016)

12. Morales-Mateos, E.Y., Hernández-Aguilar, J.A., Ochoa-Ortíz Zezzatti, C.A., López Garrido M.A.: A Comparison Represented in the Form of Radar of University Student Engagement in Degrees in Technologies. Research in Computing Science 122, pp. 141-151 (2016)

13. Hernández-Orallo, J., Ramírez-Quintana, M.J., Ferri-Ramírez, C.: Introducción a la Minería de Datos. Pearson Educación S.A. (2008)

14. Hernández, R., Fernández, C., Baptista, M.: Metodología de la investigación (5a ed.). México, D.F., México: McGraw-Hill Interamericana (2010)

15. Fayyad, U., Piatetsky-Shapiro, G., Smyth, P.: From data mining to knowledge discovery in databases. AI magazine 17(3), p. 37 (1999)

16. Niño, M.: La Relación Estilos de Aprendizaje y Rendimiento Académico en Alumnos de una Facultad de la UANL. Tesis de doctorado. Universidad Autónoma de Tamaulipas.

17. R-Project: R-Project. https://www.r-project.org/about.html (2017) 